\title{
Para-nonylphenol Toxicity Induces Oxidative Stress and Arrests the Cell Cycle in Mesenchymal Stem Cells of Bone Marrow
}

\author{
Mohammad Hussein Abnosi*iD, Sina Masoomi
}

Department of Biology, Faculty of Science, Arak University. Arak, Iran.

\begin{tabular}{|c|c|}
\hline Article Info & A B S T R A C T \\
\hline \multirow{2}{*}{$\begin{array}{l}\text { Article Type: } \\
\text { Original Research }\end{array}$} & Background: \\
\hline & The mechanism of para-nonylphenol (PNP) reducing the proliferation and \\
\hline \multirow{3}{*}{$\begin{array}{l}\text { Article History: } \\
\text { Received: } 18.05 .2019 \\
\text { Accepted: } 01.07 .20219\end{array}$} & lown. The present study was designed to investigate the mechanism. \\
\hline & Meth \\
\hline & $\begin{array}{l}\text { MSCs were extracted under sterile condition from Wistar rat and cultured } \\
\text { in DMEM, containing } 15 \% \text { FBS and penicillin/streptomycin until the } 3^{\text {rd }}\end{array}$ \\
\hline $\begin{array}{l}\text { *Corresponding Author: } \\
\text { Mohammad Hussein Abnosi } \\
\text { Department of Biology, Faculty of } \\
\text { Science, ArakUniversity. Arak, Iran } \\
\text { E-mail: m-abnosi@araku.ac.ir }\end{array}$ & $\begin{array}{l}\text { passage, then cells were treated with } 0,0.5 \text { and } 2.5 \mu \mathrm{M} \text { of PNP for } 5,10,15 \\
\text { and } 20 \text { days. We studied the viability, proliferation, cell cycle and } \\
\text { morphology of the cells. In addition, the concentration of total protein, } \\
\text { sodium, potassium and calcium and the activity of metabolic enzymes } \\
\text { (ALT, AST and LDH) were determined. Also, induction of oxidative stress } \\
\text { was estimated by determining the total antioxidant and MDA levels in } \\
\text { addition to the activity of SOD and CAT. }\end{array}$ \\
\hline
\end{tabular}

Results:

The concentrations of PNP caused a significant increase in metabolic enzymes activity and reduced the total protein dose dependently from day 5 to day 20. But only the higher PNP concentration reduced the sodium level and increased the calcium concentration during the treatment period. In addition, we observed a significant decrease in the total antioxidant level and of SOD and CAT activities whereas a significant increase in MDA was seen. Also, PNP stopped the cell cycle at "S" and "G2/M" phases.

\section{Conclusion:}

Para-NP, used in many industries, was able to reduce the viability and proliferation of the MSCs via metabolic and electrolyte imbalance and by induction of oxidative stress and cell cycle disruption.

Keywords:

Cell Cycle, Mesenchymal Stem Cells, Metabolism and Oxidative Stress, ParaNonylphenol.

How to cite this paper:

Abnosi MH, Masoomi S. Para-nonylphenol Toxicity Induces Oxidative Stress and Arrests the Cell Cycle in Mesenchymal Stem Cells of Bone Marrow. Iran J Toxicol. 2019;13 (3): 1-8

\section{INTRODUCTION}

Para-nonylphenol (PNP) is a nonionic surfactant used in such industries as food container, paper, cosmetics, leather, and detergents (1-3). It is also an environmental pollutant, traced in many foods (ㄴ) , and water $(\underline{2,5})$. Humans are exposed to PNP through various industrial products, food air and water ( $\underline{6})$. It has been found that human milk and plasma contain 56 $\mathrm{ng} / \mathrm{ml}$ and $211 \mathrm{ng} / \mathrm{g} \mathrm{PNP}$, respectively $(\underline{7,8})$. This compound accumulates in fat tissue specially brain if it enters the body of animals ( $\underline{9}$ ) due to its lipophilic property, which may lead to serious health problems. Studies have revealed a significant reduction in viability of thymocytes, jurkets, neurons, adipocytes, cancer cells, embryonic stem cells, and Sertoli cells due accelerated programmed cell death, i.e., apoptosis. In animal studies, PNP has been shown to hinder the male sexual development $(\underline{10})$, sperm production $(\underline{11})$, alter $\mathrm{T}$ cell functions $(\underline{12})$, induce apoptosis, and inhibit the $\mathrm{Ca} 2+$ pumps in sarcoplasmic and endoplasmic reticula $(\underline{13})$. Bone marrow is rich in fat (14) where PNP may accumulate, posing great hazard to the health of stem cells present in this tissue. Mesenchymal stem cells are present in bone marrow, and are the main source of bone regeneration and remodeling during homeostasis and repair (15). Abnosi et al. (16) in an in vitro investigation showed, 100 to $250 \mu \mathrm{M}$ of PNP at 24 hours caused a dose dependent reduction of rat bone marrow mesenchymal stem cells (MSCs) viability, while treatment of the cells for 48 hours reduced the viability dose dependently from 10 to $250 \mu \mathrm{M}(\underline{16})$. 
Same investigators at 2012 reviled that the viability reduction of MSCs following treatment with PNP was due to caspase dependent apoptosis as well as autophagy (17). It was also shown that the treatment of the MSCs for 21 days with 0.5 to $5 \mu \mathrm{M}$ of PNP reduces the viability, proliferation and differentiation ability due to programmed cell death $(\underline{18,19})$. In another in vivo investigation, it was shown that the MSCs extracted from PNP treated rats was not able to be subculture more than $3^{\text {rd }}$ passage, also there viability and proliferation ability of these cells reduced. The reason was found to be program cell death via caspase activation (무).

It has been reported that the PNP is able to induce oxidative stress in Sertoli, ovary and liver cells (21-23). Since the exposure to PNP in vitro and in vivo has reduced the viability, proliferation and differentiation in MSCs, the aim of this study is to investigate the mechanism of its PNP toxicity on MSCs with a focus on the oxidative stress and impact on the cells' biochemistry, morphology and proliferation.

\section{MATERIALS AND METHODS}

Marrow Cell Culture: Wistar rats (6-8 weeks old) were purchased from Pasteur Institute (Tehran, Iran) and kept in the animal holding department of Arak University under standard condition of feeding and light exposure. The animals were sacrificed by excessive chloroform inhalation (based on the standard protocol approved by Arak University of Medical Sciences). The rats' tibias and femurs were removed and separated from the soft tissue. Then, the two ends of the bones were cut off and bone marrow was flash out, using $2 \mathrm{ml}$ Dulbecco's Modified Eagles Medium, (DMEM) supplemented with 15\% Fetal Bovine Serum (FBS), $100 \mathrm{U} / \mathrm{ml}$ penicillin, and $100 \mu \mathrm{g} / \mathrm{ml}$ streptomycin. All of these chemicals were obtained from Gibco, Germany. The bone marrow content was centrifuged at $1200 \mathrm{rpm}$ for $5 \mathrm{~min}$ and resuspended in $5 \mathrm{ml}$ DMEM containing $15 \%$ FBS and antibiotics, plated in $25 \mathrm{ml}$ flasks and incubated at $37^{\circ} \mathrm{C}$ under $5 \%$ CO2. Two days after the culture, the medium was replenished and the culture medium was renewed twice a week until the bottom of the flask was confluent with the cells. The cells were trypsinized (trypsin-EDTA; Gibco, Germany) and added to a new culture flask as the first passage. These cultures were expanded through two additional subcultures for more purification of the mesenchymal stem cells which were used for the actual experimentation.

Exposure to PNP: Stock solution of PNP was prepared in DMSO. The final concentration of DMSO in culture medium was below $0.01 \%$. At this concentration, DMSO does not affect the normal cell growth (24). To perform the assays, cells were cultured in separate dishes in the presence of DMEM containing PNP $(0.5$ and $2.5 \mu \mathrm{M})$ in presence of control groups.

\section{Cell Viability Assays}

Trypan Blue Exclusion Assay: MSCs were seeded at a density of 5000 per well in 6-well culture plates and were treated with various concentration of PNP. After treating the cells for 20 days, they were washed with phosphate buffered saline (PBS), harvested with
trypsin/EDTA and centrifuged at $2500 \mathrm{rpm}$ for 5 minutes. The cells were re-suspended in $1 \mathrm{~mL}$ fresh media, then a $50 \mu \mathrm{L}$ of the suspended cell was stained with trypan blue ( $50 \mu \mathrm{L}$; Sigma Co., Germany) follow by incubation at $37^{\circ} \mathrm{C}$ for two minutes. The total number of viable cells was estimated, using a hemocytometer.

MTT Assay: The viability test was carried out on the control and treated cells in an ELISA microplate, using $10 \mu \mathrm{l}$ MTT (3-(4,5-dimethylthiazol-2-yl)-2,5- diphenyl tetrazolium bromide) solution ( $5 \mathrm{mg} / \mathrm{ml}$ of PBS). After a 4-hr incubation period, the mitochondrial succinate dehydrogenase from the live cells converted the yellow tetrazolium into violet formazan crystal. Then, $300 \mu \mathrm{l}$ DMSO was added to each well and formazan crystals were extracted following incubation at room temperature for $30 \mathrm{~min}$. The extracted solutions were transferred to new wells and the absorbance was measured at $505 \mathrm{~nm}$, using an ELISA-reader (Medical SCO GmbH; Germany).

Analysis of Morphological Changes: Following exposure to PNP in culture media for 20 days, the cells' nuclear morphology was studied, using Hoechst 33342 fluorescent dye after 15-min incubation in the dark. The dye penetrates the cells through the plasma membrane and stains the DNA, enabling the observation of the nuclear morphology such as chromatin condensation and fragmentation. The morphology of the cell cytoplasm was also examined, using acridine orange which renders the cytoplasm green. The stained cells for both analyses were washed twice with PBS, examined, and immediately photographed with an inverted fluorescence microscope (Olympus, IX70; Japan) equipped with a camera at a magnification $\mathrm{x} 400$. To measure the diameter of the nuclei $(\mu \mathrm{m})$ and cytoplasm area $\left(\mu \mathrm{m}^{2}\right)$, we used Motic Image software (Micro optical group company, version 1.2).

Quantification of Cell Proliferation: The cell proliferation was quantified after the third passage via colony forming assay and the cell population doubling number (PDN).

Colony Forming Assay: The colony forming ability of the cells was evaluated with $10^{4}$ cells separately seeded in $3-\mathrm{cm}$ sterile plates. After treating the cells with 0.5 or $2.5 \mu \mathrm{M}$ of PNP, the sets of culture plates were incubated for 5, 10, 15 or 20 days. The culture media containing PNP were replenished every three days. After rinsing the plates with PBS, crystal violet staining $(0.5 \mathrm{~g}$ crystal violet in $100 \mathrm{~mL}$ methanol) was performed and the diameter $(\mu \mathrm{m})$ and number of the colonies were estimated, using a light microscope equipped with graticule.

Population Doubling Number: To estimate the PDN, $2 \times 10^{4}$ cells were separately seeded in $3-\mathrm{cm}$ sterile plates. After treating the cells with 0.5 or $2.5 \mu \mathrm{M}$ of PNP, they were incubated for $5,10,15$ or 20 days with the media replenished every three days. After washing the plate with PBS, cells were harvested with trypsin/EDTA, and the number of the cells was counted using a hemocytometer. Using the equation: PDN $=\log$ $\mathrm{N} / \mathrm{N}_{0} \times 3.31$, the population doubling number of the cells was determined, where $\mathrm{N}_{0}$ was the initial number of the 
cells seeded and $\mathrm{N}$ represented the number of the cells at the completion of the culture period.

Preparation of Cell Extract: Control and experimentally treated cells were incubated for 5,10 , 15 or 20 days in the media containing 0.5 or $2.5 \mu \mathrm{M}$ PNP. The culture dishes were trypsinized followed by centrifugation at $2500 \mathrm{rpm}$ for 5 minutes to harvest the cells. After washing the cells with Tris- $\mathrm{HCl}$, they were homogenized in lysis buffer (20 mM Tris- $\mathrm{HCl}, \mathrm{pH} 7.2)$ and kept at $-20^{\circ} \mathrm{C}$ overnight. Finally, the homogenate was centrifuged at $12000 \mathrm{~g}$ for 10 minutes to extract the intracellular contents. Using Lowry method, the total protein content of each homogenate sample was determined. Using bovine serum albumin (BSA) a standard plot was drawn and the concentration of protein in the samples was calculated, based on the formula: $\mathrm{Y}=0.3169 \mathrm{X}+0.00001$ with $\mathrm{R}^{2}=0.9992$, where $\mathrm{Y}$ was the absorbance and $\mathrm{X}$ the protein concentration $(\mu \mathrm{g})$ in each sample. Each analysis of the biochemical factors was carried out based on an equal amount of the protein in the cell lysate.

Determination of Transaminase and Lactate Dehydrogenase Activities: The activities of the alanine transaminase (ALT), aspartate transaminase (AST) and lactate dehydrogenase (LDH) in the cell lysate were determined, using a commercial kit (Pars Azmoon, Iran) and based on the manufacturer's established guideline. The absorbance was determined measured at $340 \mathrm{~nm}$, using a spectrophotometer (T80+; PG Instrument Ltd.; England).

Calcium Concentration: The calcium content of the cell lysate was determined at $630 \mathrm{~nm}$ using spectrophotometer (T80+; PG instrument ltd; England) according to the instruction provided by the commercial kit (Pars Azmoon, Iran). The concentration of calcium was calculated by the linear formula: $\mathrm{Y}=0.002 \mathrm{X}-0.0009$ with $\mathrm{R}^{2}=0.998$, where $\mathrm{Y}$ was the absorbance and $X$ the calcium concentration $(\mathrm{mg} / \mathrm{dL})$.

\section{Determination of Sodium and Potassium} Concentrations: The amount of $\mathrm{Na}+$ and $\mathrm{K}+$ in the cell lysate was determined using a flame photometer (Model PFP7; England), where $\mathrm{Na}^{+}$and $\mathrm{K}^{+}$emitted light at different wavelength each. The emission may be measured using appropriate filters, corresponding to the respective element and concentrations. We used the same instrument and different concentrations of $\mathrm{NaCl}$ and $\mathrm{KCl}$ to plot a standard graph. The linear formula $\left(\mathrm{Y}=0.0171 \mathrm{X}+0.00054\right.$ with $\mathrm{R}^{2}=0.9988$ and $\mathrm{Y}=0.3203 \mathrm{X}+0.0667$ with $\mathrm{R}^{2}=0.9983$ were obtained for $\mathrm{Na}^{+}$and $\mathrm{K}^{+}$, respectively, where $\mathrm{Y}$ was the absorbance and $X$ the concentration of each electrolyte $(\mu \mathrm{g} / \mathrm{dl})$.

Effect of PNP on Oxidative Stress: Ferric reducing ability power (FRAP) was performed by mixing $150 \mu \mathrm{l}$ of sample with $1700 \mu \mathrm{l}$ of FRAP solution containing (2.5 mL of a $10-\mathrm{mmol} / \mathrm{L} \mathrm{TPTZ} \mathrm{solution} \mathrm{in} 40 \mathrm{mmol} / \mathrm{L}$ $\mathrm{HCl}, 2.5 \mathrm{~mL}$ of $10 \mathrm{mmol} / \mathrm{L} \mathrm{FeCl}_{3}$ and $25 \mathrm{~mL}$ of $0.1 \mathrm{~mol} / \mathrm{L}$ acetate buffer) at $\mathrm{pH} 3.6$, and $850 \mu \mathrm{l}$ distilled water follow by 10 minutes incubation at dark then measuring the absorbance at $593 \mathrm{~nm}$. A standard graph was plotted, using varying concentration of $\mathrm{FeSo}_{4}, 7 \mathrm{H}_{2} \mathrm{O}$ and the total antioxidant power of the samples was calculated, using the linear formula $\mathrm{Y}=0.0134 \mathrm{X}+0.0173$ with $\mathrm{R}^{2}=0.9983$, where $\mathrm{Y}$ was the absorbance and $\mathrm{X}$ the concentration.

Malondialdehyde (MDA), formed as a byproduct of the peroxidation of lipids, served as an index of the intensity of oxidative stress. MDA reacts with thiobarbituric acid to generate a colored product that can be measured optically at $523 \mathrm{~nm}$. Briefly, $1 \mathrm{ml}$ of the stock solution (containing equal volumes of trichloroacetic acid 20\% (w/v) and thiobarbituric acid $0.5 \%(\mathrm{w} / \mathrm{v}))$ was mixed with $50 \mu$ l of cell extract $\left(2 \times 10^{6}\right.$ MSCs homogenized in PBS) in a screw-capped centrifuge tube, vortexed and heated for $30 \mathrm{~min}$ in a boiling water bath. After cooling on ice for 15 minutes, the precipitate was removed by centrifugation at $1000 \mathrm{~g}$ for $10 \mathrm{~min}$ and the absorbance of the supernatant was measured at $523 \mathrm{~nm}$ against a blank that contained all of the reagents except for the test sample. The value was expressed as $\mu \mathrm{M}$ using the formula $\mathrm{A}=\varepsilon \mathrm{bc}$, where $\varepsilon=155 \mathrm{mmol}-1 \mathrm{~cm}-1, \mathrm{~A}=$ absorbance, $\mathrm{B}=$ cuvette width $(1 \mathrm{~cm})$ and $\mathrm{C}=$ concentration of MDA.

The catalase (CAT) activity was determined by measuring the rate of $\mathrm{H}_{2} \mathrm{O}_{2} \quad\left(10 \mathrm{mmol} \mathrm{l}^{-1}\right)$ decomposition in $25 \mathrm{mmol} \mathrm{l}^{-1}$ potassium phosphate buffer, ( $\mathrm{pH} \mathrm{7.0),} \mathrm{at} 240 \mathrm{~nm}$ and $25^{\circ} \mathrm{C}$. The activity was calculated based on $\mu$ mols of $\mathrm{H} 2 \mathrm{O} 2$ consumed $/ \mathrm{min} / \mathrm{mg}$ of protein, using the molar extinction coefficient of 43.1 $\mathrm{M}^{-1} \mathrm{~cm}^{-1}$.

The superoxide dismutase (SOD) activity was analyzed by measuring its ability to inhibit the photochemical reduction of nitro blue tetrazolium (NBT). $1 \mathrm{ml}$ of the reaction mixture $(50 \mathrm{mM}$ phosphate buffer, $\mathrm{pH} 7.8,26$ $\mathrm{mM}$ methionine, $20 \mu \mathrm{M}$ riboflavin, $750 \mu \mathrm{M}$ NBT and $1 \mu \mathrm{M}$ EDTA) was mixed with $50 \mu$ l of the cell extract $\left(2 \times 10^{6}\right.$ MSCs homogenized in PBS) and the reaction was run 15 min under light. The control was run in dark without having the cell extract. The absorbance was read at $560 \mathrm{~nm}$ and the activity was calculated by subtracting the absorbance of the control and sample divided by absorbance of control.

Cell Cycle: After the third passage, cells were cultured in a $\mathrm{T}_{25}$ flask and treated with 0.5 or $2.5 \mu \mathrm{M}$ of PNP for 20 days. Subsequently, they were washed with PBS and detached from bottom of the flask using trypsin/EDTA. Aliquots of cells $\left(10^{6}\right)$ were centrifugation at $2500 \mathrm{rpm}$ for 5 minutes and resuspended in $1.2 \mathrm{ml}$ of PBS, then fixed with the addition of $3 \mathrm{ml}$ of $95 \%$ cold ethanol drop-wise followed by the addition of $7.8 \mathrm{ml}$ of $70 \%$ cold ethanol, and the final volume of the solution was adjusted to $15 \mathrm{ml}$ by adding PBS. The cells were centrifuged at $2000 \mathrm{rpm}$ for 10 minutes and suspended in $1 \mathrm{ml}$ Diaminophenyl indole phosphate (DAPI; $1 \mu \mathrm{g} / \mathrm{ml}$ ) and incubated for 30 minutes at $4{ }^{\circ} \mathrm{C}$. Finally, the cells were washed with PBS and cell cycle was analyzed using a flowcytometer (Germany, PARTEC (PAS)).

Statistical Analysis: The statistical analysis of the data was performed using one-way analysis of variance (ANOVA) and Tukey's tests on SPSS version 11. The results were presented as mean \pm SD and $P<0.05$ was accepted as the minimum level of significance. 


\section{RESULTS}

Cell Viability: The results of trypan blue staining showed a significant dose dependent reduction $(P<0.05)$ of cell viability after 20 days of exposure to PNP compared with the controls (Table 1). The viability of MSCs, based on MTT assay, also confirmed the results of trypan blue staining. For the cells treated for 20 days, significant differences $(P<0.05)$ was observed, compared with the controls (Table 1).

Cell Morphology: Study of the cell morphology showed that the nuclei diameter and cytoplasm area changed significantly $(P<0.05)$ and dose dependently when MSCs were exposed to 0.5 or $2.5 \mu \mathrm{M}$ of PNP for 20 days (Table 1). The morphological changes in nuclei and cytoplasm were also confirmed by microscopic examination. The morphological changes were chromatin condensation, nuclear breakage (Figure 1b and 1c) and cytoplasm shrinkage as well as disappearance of cytoplasm in some cells (Figure $2 \mathrm{~b}$ and $2 \mathrm{c}$ ).

Colony Forming Assay: The analysis of data showed that treatment of the cells with 0.5 or $2.5 \mu \mathrm{M}$ PNP reduced the number of colonies significantly in a dose dependent manner $(P<0.05)$ on days 15 and 20 (Table 2); however, no changes were observed on days 5 and 10. There was a significant and dose dependent reduction in colonies diameter $(P<0.05)$ on day 20 only (Table 2).

Population Doubling Number: The population doubling number declined was significantly $(\mathrm{p}<0.05)$ by exposure to $0.5 \mu \mathrm{M}$ PNP only after 20 days of culture, whereas $2.5 \mu \mathrm{M}$ PNP caused a highly significant reduction in DPN $(\mathrm{P}<0.001)$ after 10,15 or 20 days of exposure (Table 2).

Determination of Total Protein Concentration: The MSCs treated with 0.5 or $2.5 \mu \mathrm{M}$ of PNP for $5,10,15$ or 21 days, showed a significant dose dependent reduction $(\mathrm{P}<0.05)$ in total protein concentration compared to the controls (Table 3 ).

Metabolic Activity of Cells: The MSCs treated with 0.5 or $2.5 \mu \mathrm{M}$ of PNP showed a significant dose dependent increase $(P<0.05)$ in transaminase activities (ALT \& AST) for all of the treatment periods compared with the controls (Table 3 ). In addition, we observed a significant dose dependent increase $(P<0.05)$ in the activity of LDH following treatment with 0.5 or $2.5 \mu \mathrm{M}$ PNP for all the treatment periods (Table 3).

Determination of Electrolytes: Treatment with 0.5 $\mu \mathrm{M}$ PNP caused no significant changes $(P>0.05)$ in the calcium content for any exposure period compared with those in the control group. However, we found a significant increase $(P<0.05)$ in the $2.5 \mu \mathrm{M}$ PNP group from day 10 onward compared with those in the control group (Table 4). Treatment with 0.5 or $2.5 \mu \mathrm{M}$ of PNP caused a significant dose dependent reduction $(P<0.05)$ in the sodium content as compared with controls for all the experimental periods (Table 4). However, no significant changes $(P>0.05)$ was found in the potassium content of the cells compared to those in the control group (Table 4).

Effect of PNP on Oxidative Stress: The MSCs treated with 0.5 or $2.5 \mu \mathrm{M}$ of PNP showed a significant dose dependent reduction $(P<0.05)$ in FRAP (Table 5) and the elevation of MDA $(P<0.05)$ compared with the control group (Table 5). Further, There was a significant reduction $(P<0.05)$ in CAT and SOD activities dose dependently compared to the control group (Table 5).

Cell Cycle: The cell cycle analysis revealed that the cells' treatment with $0.5 \mu \mathrm{M}$ of PNP caused it to move from G1 and was arrested at S phase (Table 6; Figure $3 \mathrm{~B})$. In addition, we found that the $2.5 \mu \mathrm{M}$ PNP treatment arrested the cell cycle not only at $S$ phase but also at G2/M phase (Table 6; Figure 3C) compared with the controls.

Table 1. Comparison of the mean percentage of the cell viability based on trypan blue staining and the mean cell numbers based on MTT assay and morphological parameters after 20 days of exposure to PNP.

\begin{tabular}{ccccc} 
& \multicolumn{2}{c}{ morphological parameters after 20 days of exposure to PNP. } \\
\cline { 2 - 5 } PNP & \multicolumn{2}{c}{ Cell Viability } & \multicolumn{2}{c}{ Cell Morphology } \\
\cline { 2 - 5 } & $\begin{array}{c}\text { Cells Number } \\
\text { (MTT-based) }\end{array}$ & $\begin{array}{c}\text { Viable Cells \% } \\
\text { (trypan blue) }\end{array}$ & $\begin{array}{c}\text { Mean Cytoplasm } \\
\text { Area }\left(\boldsymbol{\mu m ^ { 2 }}\right)\end{array}$ & $\begin{array}{c}\text { Mean Nuclei } \\
\text { Diameter }(\boldsymbol{\mu m})\end{array}$ \\
\hline $0 \mu \mathrm{M}$ & $23403.39^{\mathrm{a}} \pm 36.77$ & $96.99^{\mathrm{a}} \pm 0.17$ & $1838.70^{\mathrm{a}} \pm 27.93$ & $16.46^{\mathrm{a}} \pm 0.11$ \\
$0.5 \mu \mathrm{M}$ & $12511.67^{\mathrm{b}} \pm 350.80$ & $84.81^{\mathrm{b}} \pm 0.83$ & $1244.46^{\mathrm{b} \pm 5.59}$ & $15.66^{\mathrm{b} \pm 0.10}$ \\
$2.5 \mu \mathrm{M}$ & $10600.84^{\mathrm{c}} \pm 389.17$ & $72.67^{\mathrm{c}} \pm 0.35$ & $811.57^{\mathrm{c}} \pm 7.82$ & $9.62^{\mathrm{c}} \pm 0.27$ \\
\hline
\end{tabular}

In each column, means with letter codes $(\mathrm{a}, \mathrm{b}, \mathrm{c})$ differed significantly from each other $(\mathrm{P}<0.05)$. Values shown are means \pm SD.

Table 2. Proliferation Analysis: Comparison of the mean cell number for the colonies, diameter and PDN of the bone marrow MSCs after $5,10,15$ or 20 days of treatment with PNP.

\begin{tabular}{lclll}
\hline & \multicolumn{3}{c}{ PNP Dose } \\
\cline { 2 - 5 } & Time (day) & \multicolumn{1}{c}{$\mathbf{0} \boldsymbol{\mu M}$} & $\mathbf{0 . 5} \boldsymbol{\mu M}$ & $\mathbf{2 . 5} \boldsymbol{\mu M}$ \\
\hline Colony & 5 & $2.33^{\mathrm{a}} \pm 0.57$ & $2.33^{\mathrm{a}} \pm 1.15$ & $2.01^{\mathrm{a}} \pm 1.11$ \\
Number & 10 & $8.33^{\mathrm{a}} \pm 0.57$ & $8.06^{\mathrm{a}} \pm 0.21$ & $7^{\mathrm{a}} \pm 0.57$ \\
& 15 & $51.53^{\mathrm{a}} \pm 4.35$ & $41.20^{\mathrm{b}} \pm 3.60$ & $32.66^{\mathrm{c}} \pm 3.51$ \\
Colony Diameter & 20 & $62.33^{\mathrm{a}} \pm 4.16$ & $52.10^{\mathrm{b}} \pm 3.32$ & $28.66^{\mathrm{c}} \pm 2.08$ \\
& 5 & $1.09^{\mathrm{a}} \pm 0.06$ & $1.11^{\mathrm{a}} \pm 0.07$ & $1.07^{\mathrm{a}} \pm 0.09$ \\
& 10 & $1.12^{\mathrm{a}} \pm 0.04$ & $1.12^{\mathrm{a}} \pm 0.03$ & $1.10^{\mathrm{a} \pm 0.05}$ \\
& 15 & $2.09^{\mathrm{a}} \pm 0.12$ & $2.03^{\mathrm{a}} \pm 0.10$ & $2.03^{\mathrm{a}} \pm 0.02$ \\
Population doubling & 20 & $3.07^{\mathrm{a}} \pm 0.11$ & $1.95^{\mathrm{b}} \pm 0.06$ & $1.86^{\mathrm{c} \pm 0.08}$ \\
number & 5 & $1.11^{\mathrm{a}} \pm 0.04$ & $1.10^{\mathrm{a}} \pm 0.02$ & $1.09^{\mathrm{a}} \pm 0.06$ \\
& 10 & $1.57^{\mathrm{a}} \pm 0.06$ & $1.40^{\mathrm{a}} \pm 0.04$ & $0.83^{\mathrm{b}} \pm 0.05$ \\
& 15 & $1.94^{\mathrm{a}} \pm 0.04$ & $1.66^{\mathrm{a}} \pm 0.08$ & $0.69^{\mathrm{b}} \pm 0.11$ \\
& 20 & $2.34^{\mathrm{a}} \pm 0.03$ & $1.26^{\mathrm{b}} \pm 0.11$ & $0.49^{\mathrm{c}} \pm 0.07$ \\
\hline
\end{tabular}

In each row, means with different letter codes $(\mathrm{a}, \mathrm{b}, \mathrm{c})$ differ significantly from each other $(\mathrm{P}<0.05)$.

Values shown are means \pm SD. 
Table 3. Comparison of the total protein concentration $(\mu \mathrm{g} / \mathrm{ml})$ and activity (IU/L) of ALT, AST and LDH enzymes in the rats bone marrow MSCs after 5, 10, 15 or 20 days of treatment with PNP.

\begin{tabular}{|c|c|c|c|c|}
\hline & \multicolumn{4}{|c|}{ PNP Dose } \\
\hline & Time (day) & $\mathbf{0 \mu M}$ & $0.5 \mu \mathrm{M}$ & $2.5 \mu \mathrm{M}$ \\
\hline \multirow[t]{4}{*}{ Total protein } & 5 & $21.33^{\mathrm{a}} \pm 1.02$ & $13.66^{\mathrm{b}} \pm 1.74$ & $8.97^{c} \pm 1.05$ \\
\hline & 10 & $24.92^{\mathrm{a}} \pm 1.06$ & $18.55^{\mathrm{b}} \pm 1.83$ & $13.33^{\mathrm{c}} \pm 1.21$ \\
\hline & 15 & $28.66^{\mathrm{a}} \pm 2.87$ & $24.59^{\mathrm{b}} \pm 1.73$ & $20.31^{c} \pm 1.69$ \\
\hline & 20 & $27.65^{\mathrm{a}} \pm 1.19$ & $22.01^{\mathrm{b}} \pm 2.04$ & $20.04^{c} \pm 2.10$ \\
\hline Alanine & 5 & $7.72^{\mathrm{a}} \pm 0.38$ & $11.91^{\mathrm{b}} \pm 1.02$ & $27.79^{c} \pm 1.09$ \\
\hline \multirow{3}{*}{ transaminase } & 10 & $7.94^{\mathrm{a}} \pm 1.03$ & $16.10^{\mathrm{b}} \pm 0.38$ & $30.43^{c} \pm 1.14$ \\
\hline & 15 & $7.94^{\mathrm{a}} \pm 1.10$ & $19.85^{\mathrm{b}} \pm 1.10$ & $37.71^{c} \pm 3.06$ \\
\hline & 20 & $8.16^{\mathrm{a}} \pm 0.38$ & $19.85^{\mathrm{b}} \pm 2.10$ & $41.02^{\mathrm{c}} \pm 5.09$ \\
\hline Aspartate & 5 & $5.73^{\mathrm{a}} \pm 0.38$ & $17.86^{\mathrm{b}} \pm 1.02$ & $39.92^{c} \pm 4.08$ \\
\hline \multirow[t]{3}{*}{ transaminase } & 10 & $5.95^{\mathrm{a}} \pm 1.04$ & $19.62^{\mathrm{b}} \pm 2.38$ & $43.67^{c} \pm 6.10$ \\
\hline & 15 & $5.95^{\mathrm{a}} \pm 1.01$ & $22.06^{\mathrm{b}} \pm 4.39$ & $46.99^{c} \pm 6.38$ \\
\hline & 20 & $6.17^{a} \pm 0.37$ & $25.80^{\mathrm{b}} \pm 5.04$ & $49.62^{c} \pm 6.40$ \\
\hline Lactate & 5 & $20.19^{\mathrm{a}} \pm 1.03$ & $39.12^{\mathrm{b}} \pm 1.08$ & $80.09^{c} \pm 4.01$ \\
\hline \multirow[t]{3}{*}{ dehydrogenase } & 10 & $20.17^{\mathrm{a}} \pm 1.07$ & $39.69^{\mathrm{b}} \pm 1.09$ & $100.12^{\mathrm{c}} \pm 5.04$ \\
\hline & 15 & $20.21^{\mathrm{a}} \pm 1.08$ & $59.94^{\mathrm{b}} \pm 7.05$ & $160.41^{c} \pm 15.20$ \\
\hline & 20 & $20.23^{\mathrm{a}} \pm 2.08$ & $59.88^{\mathrm{b}} \pm 4.09$ & $199.97 \_ \pm 19.04$ \\
\hline
\end{tabular}

In each row, means with different letter codes $(\mathrm{a}, \mathrm{b}, \mathrm{c})$ differ significantly from each other $(\mathrm{P}<0.05)$.

Values shown are means \pm SD.

Table 4. Comparison of the mean calcium (mg/dl), sodium $(\mu \mathrm{g} / \mathrm{dl})$ and potassium $(\mu \mathrm{g} / \mathrm{dl})$ contents of the bone marrow cells after $5,10,15$ or 20 days of treatment with PNP.

\begin{tabular}{lcccc}
\hline & \multicolumn{4}{c}{ Doses } \\
\cline { 2 - 5 } Calcium & Time (day) & $\mathbf{0 ~} \boldsymbol{\mu M}$ & $\mathbf{0 . 5} \boldsymbol{\mu} \mathbf{M}$ & $\mathbf{2 . 5} \boldsymbol{\mu M}$ \\
& 5 & $2.35^{\mathrm{a}} \pm 0.86$ & $2.35^{\mathrm{a}} \pm 0.86$ & $2.40^{\mathrm{a}} \pm 0.80$ \\
& 10 & $3.05^{\mathrm{a}} \pm 0.32$ & $3.18^{\mathrm{a}} \pm 0.09$ & $4.70^{\mathrm{b} \pm 0.09}$ \\
& 15 & $5.48^{\mathrm{a}} \pm 0.23$ & $5.62^{\mathrm{a}} \pm 0.09$ & $7.05^{\mathrm{b}} \pm 0.12$ \\
Sodium & 20 & $5.64^{\mathrm{a}} \pm 0.25$ & $5.79^{\mathrm{a}} \pm 0.16$ & $7.52^{\mathrm{a}} \pm 0.18$ \\
& 5 & $2.195^{\mathrm{a}} \pm 0.03$ & $1.61^{\mathrm{b}} \pm 0.05$ & $1.20^{\mathrm{a}} \pm 0.05$ \\
& 10 & $2.17^{\mathrm{a}} \pm 0.03$ & $1.59^{\mathrm{b}} \pm 0.03$ & $1.02^{\mathrm{c}} \pm 0.01$ \\
Potassium & $1.99^{\mathrm{a}} \pm 0.04$ & $1.59^{\mathrm{b}} \pm 0.03$ & $0.59^{\mathrm{c}} \pm 0.03$ \\
& 20 & $1.99^{\mathrm{a}} \pm 0.04$ & $1.43^{\mathrm{b}} \pm 0.03$ & $0.46^{\mathrm{c}} \pm 0.03$ \\
& 5 & $0.33^{\mathrm{a}} \pm 0.01$ & $0.33^{\mathrm{a}} \pm 0.01$ & $0.33^{\mathrm{a}} \pm 0.05$ \\
& 10 & $0.33^{\mathrm{a}} \pm 0.01$ & $0.33^{\mathrm{a}} \pm 0.05$ & $0.33^{\mathrm{a}} \pm 0.01$ \\
& 15 & $0.35^{\mathrm{a}} \pm 0.05$ & $0.35^{\mathrm{a}} \pm 0.06$ & $0.35^{\mathrm{a}} \pm 0.06$ \\
& 20 & $0.35^{\mathrm{a}} \pm 0.02$ & $0.35^{\mathrm{a}} \pm 0.01$ & $0.35^{\mathrm{a}} \pm 0.01$ \\
\hline
\end{tabular}

In each row, means with different letter codes $(\mathrm{a}, \mathrm{b}, \mathrm{c})$ differ significantly from each other $(\mathrm{P}<0.05)$.

Values shown are means \pm SD.

Table 5. Comparison of the total antioxidant level ( $\left.\mu \mathrm{M} \mathrm{mg}{ }^{-1} \mathrm{FW}\right)$, Malondialdehyde concentration ( $\left.\mu \mathrm{M}\right)$, Catalase and superoxide dismutase activities (unit min $^{-1} \mathrm{mg}^{-1}$ protein) of bone marrow cells after $5,10,15$ or 20 days of treatment with PNP.

\begin{tabular}{|c|c|c|c|c|}
\hline & & \multicolumn{3}{|c|}{ Doses } \\
\hline & Time (day) & $0 \mu \mathrm{M}$ & $0.5 \mu \mathrm{M}$ & $2.5 \mu \mathrm{M}$ \\
\hline Total antioxidant & 5 & $1.24^{\mathrm{a}} \pm 0.04$ & $0.99^{b} \pm 0.03$ & $1.20^{\mathrm{c}} \pm 0.01$ \\
\hline \multirow[t]{3}{*}{ level } & 10 & $1.22^{\mathrm{a}} \pm 0.04$ & $0.87^{b} \pm 0.05$ & $0.15^{\mathrm{c}} \pm 0.02$ \\
\hline & 15 & $1.17^{\mathrm{a}} \pm 0.03$ & $0.7^{\mathrm{b}} \pm 0.04$ & $0.12^{\mathrm{c}} \pm 0.02$ \\
\hline & 20 & $1.14^{\mathrm{a}} \pm 0.04$ & $0.69^{b} \pm 0.03$ & $0.05^{\mathrm{c}} \pm 0.01$ \\
\hline Malondialdehyde & 5 & $0.03^{\mathrm{a}} \pm 0.03$ & $0.14^{\mathrm{b}} \pm 0.04$ & $0.26^{c} \pm 0.02$ \\
\hline \multirow[t]{3}{*}{ concentration } & 10 & $0.03^{a} \pm 0.03$ & $0.18^{b} \pm 0.02$ & $0.30^{c} \pm 0.03$ \\
\hline & 15 & $0.03^{a} \pm 0.02$ & $0.21^{b} \pm 0.03$ & $0.33^{c} \pm 0.03$ \\
\hline & 20 & $0.03^{a} \pm 0.03$ & $0.25^{b} \pm 0.01$ & $0.38^{\mathrm{c}} \pm 0.04$ \\
\hline \multirow[t]{4}{*}{ Catalase activity } & 5 & $5.30^{a} \pm 0.13$ & $3.71^{\mathrm{b}} \pm 0.11$ & $1.02^{\mathrm{c}} \pm 0.03$ \\
\hline & 10 & $5.21^{\mathrm{a}} \pm 0.22$ & $2.83^{\mathrm{b}} \pm 0.01$ & $0.96^{c} \pm 0.02$ \\
\hline & 15 & $5.13^{\mathrm{a}} \pm 0.31$ & $2.54^{\mathrm{b}} \pm 0.04$ & $0.73^{\mathrm{c}} \pm 0.01$ \\
\hline & 20 & $4.74^{\mathrm{a}} \pm 0.64$ & $2.15^{b} \pm 0.01$ & $0.9^{c} \pm 0.01$ \\
\hline Superoxide & 5 & $5.78^{a} \pm 0.03$ & $5.32^{\mathrm{b}} \pm 0.10$ & $3.62^{\mathrm{c}} \pm 0.20$ \\
\hline \multirow[t]{3}{*}{ dismutase } & 10 & $5.74^{a} \pm 0.10$ & $5.02^{\mathrm{b}} \pm 0.10$ & $3.50^{c} \pm 0.20$ \\
\hline & 15 & $5.92^{\mathrm{a}} \pm 0.10$ & $4.77^{b} \pm 0.10$ & $2.54^{\mathrm{c}} \pm 0.10$ \\
\hline & 20 & $6.25^{\mathrm{a}} \pm 0.09$ & $4.59^{b} \pm 0.10$ & $2.11^{\mathrm{c}} \pm 0.10$ \\
\hline
\end{tabular}

In each row, means with different letter codes $(\mathrm{a}, \mathrm{b}, \mathrm{c})$ differ significantly from each other $(\mathrm{P}<0.05)$.

Values shown are means \pm SD.

Table 6. Cell DNA Content Analysis of MSCs after 20 Days of Treatment with Different PNP Concentration.

\begin{tabular}{cccc} 
Phase & G1 & $\mathrm{S}$ & $\mathrm{G} 2 / \mathrm{M}$ \\
\hline $0 \mu \mathrm{M}$ & $80.15^{\mathrm{a}} \pm 8.75$ & $1.45^{\mathrm{a}} \pm 0.10$ & $18.40^{\mathrm{a}} \pm 1.20$ \\
$0.5 \mu \mathrm{M}$ & $51.90^{\mathrm{b}} \pm 6.40$ & $29.74^{\mathrm{b}} \pm 4.11$ & $18.36^{\mathrm{a}} \pm 2.08$ \\
$2.5 \mu \mathrm{M}$ & $43.77^{\mathrm{c}} \pm 6.31$ & $27.36^{\mathrm{b}} \pm 3.90$ & $28.87^{\mathrm{b}} \pm 3.26$ \\
\hline
\end{tabular}

In each row, means with different letter codes $(\mathrm{a}, \mathrm{b}, \mathrm{c})$ differ significantly from each other $(\mathrm{P}<0.05)$.

Values shown are means \pm SD. 

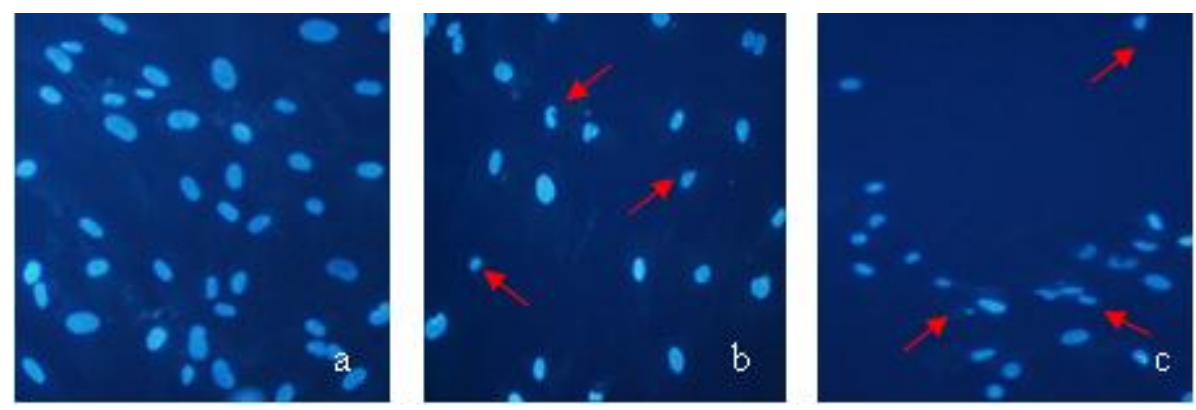

Figure 1. MSCs stained with Hoechst, after 20 days of treatment with PNP: (a) controls, (b) $0.5 \mu M$ PNP, (c) $2.5 \mu M$ PNP. Arrows show changes in the nuclei (chromatin breakage \& condensation). Mag: X 20.
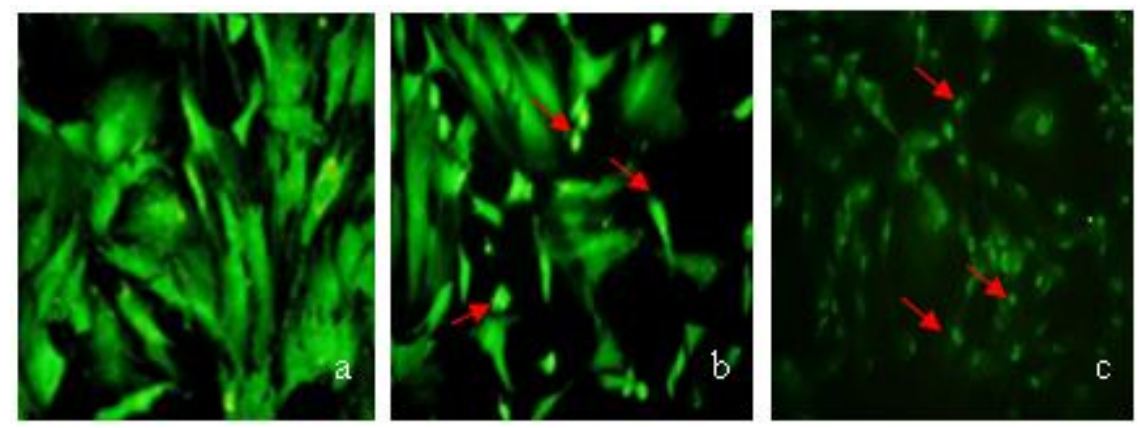

Figure 2. MSCs stained with acridine orange, after 20 days of treatment with PNP: (a) Control, (b) $0.5 \mu \mathrm{M}$ PNP (c) $2.5 \mu \mathrm{M}$ PNP. Arrows show the cytoplasmic changes (shrinkage or disappearance).

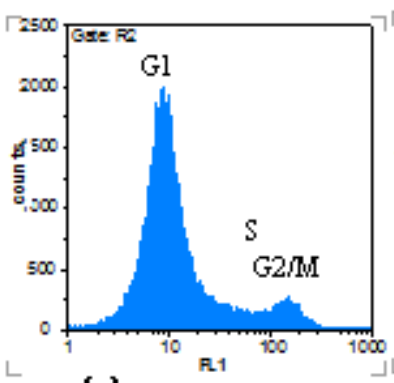

(a)

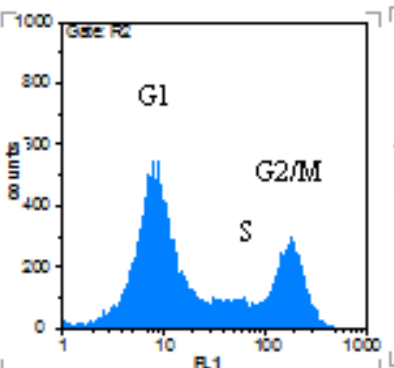

(b)

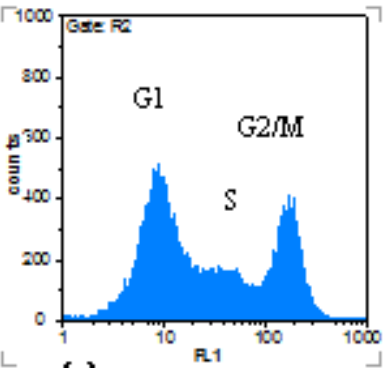

(c)

Figure 3. Cellular DNA analysis by DAPI staining and histogram interpretation of the DNA content of MSCs after 20 days of treatment with PNP: a) Control, b) $0.5 \mu \mathrm{m}$, and c) $2.5 \mu \mathrm{m}$ PNP.

\section{DISCUSSION}

Cell Viability: In 2011 and 2012, Abnosi et al. demonstrated that the treatment of rat bone marrow MSCs with 0.5 and $2.5 \mu \mathrm{M}$ PNP significantly decreased the viability and proliferation after 21 days; however, the mechanism was unclear $(18,19)$. In this study, trypan blue staining and MTT assay confirmed that the viability of MSCs treated with 0.5 or $2.5 \mu \mathrm{M}$ PNP over 20 days was significantly reduced compared with the controls. Trypan blue cannot cross intact cell membranes, but can enter the cells if the membrane is damaged (25). Also, yellow formazan crystallized due to its reduction by dehydrogenase enzymes, such as succinate dehydrogenase, which is a complex II for electron transport chain (26). Therefore, the tests in this study showed that the cell membranes function and the metabolism had been affected due to the PNP treatment. The integrity of cell membrane depends on the electrical potential, which is maintained by well balanced electrolytes in the cell wall (그). In addition to electrolyte balance, the membrane integrity depends on the structure of the fatty acids in the lipid bilayers (28). Our results showed that the PNP treatment of the cells caused imbalance in the sodium level starting from day 5 onward to day 20 in response to PNP at 0.5 or $2.5 \mu \mathrm{M}$. On the other hand, the calcium level elevated mainly due to the higher PNP concentration $(2.5 \mu \mathrm{M})$. It is unlikely that the imbalance in the electrolytes happened due to malfunctioning of the $\mathrm{Na}^{+} / \mathrm{K}^{+}$pump (29), but it might be due to reversibility of $\mathrm{Na}^{+} / \mathrm{Ca}^{++}$ exchanger ( $\underline{30})$, which has caused the influx of calcium and outflow of sodium.

Cell Metabolic Integrity: It was also shown that the metabolic activity of the cells changed, since the enzymatic analysis revealed significant elevations in the ALT, AST and HDL activities following treatment with 0.5 or $2.5 \mu \mathrm{M}$ PNP.Krebs cycle (TCA) is the main metabolic process which feeds the electron transport chain with the carriers $\left(\mathrm{NADH}+\mathrm{H}^{+}\right.$and $\left.\mathrm{FADH}_{2}\right)$. Also, the intermediate carrier, especially oxaloacetate, is an important factor which enables the breakdown of carbohydrate and fat molecules. When the cellular 
energy demand increases, the breakdown of carbohydrate and fat molecules provide additional acetyl-CoA for entry into Krebs cycle. This process also requires oxaloacetate. Transamination enzymes (ALT and AST) which are involved in amino acid metabolism, convert alpha-ketoglutarate to glutamate and further convert oxaloacetate to aspartate where consequently alanine will be converted to pyruvate. This means that the carbon skeleton of the amino acids is used as the energy source. On the other hand, the rise in LDH shows that the cell has been faced with oxygen shortage, shifting to anaerobic metabolism (31). In this study, the reduction in the cell viability and metabolism was proven through MTT assay.

Oxidative Stress: In addition to electrolyte imbalance and adverse metabolic changes, the analysis of the oxidative stress proved that the PNP has the ability to induce the unsaturated fatty acids to undergo oxidation and produce MDA starting from the day 5 to 20 of the treatment period. Production of MDA is a significant sign of oxidative stress, which together with a reduction in anti-oxidative ability of the cell can destroy the membrane integrity. It is well documented that the PNP induces oxidative stress on the cells $(\underline{32})$ in variety of fish. This study for the first time, demonstrated that PNP can induce oxidative stress in MSCs, providing a putative mechanism behind membrane disruption and cell viability reduction.

Meanwhile we found that cell proliferation with respect to PDN and colony forming ability (CFA) also was affected by PNP treatment. The latter is the characteristic of a cell to divide and form a colony of the same cell cells that share a common ancestry ( $\underline{33})$. In this context, PNP caused a significant reduction in the number and diameter of the colonies at day 20, suggesting that the cells lost the ability to go through mitotic cell division. This was also confirmed by PDN, which was reduced significantly at day 20 dose dependently. Analysis of the cell cycle revealed that the cell division process was arrested at $S$ phase in response to $0.5 \mu \mathrm{M}$ PNP and the higher concentration $(2.5 \mu \mathrm{M})$ halted the cell cycle at $\mathrm{S}$ and $\mathrm{G} 2 / \mathrm{M}$ phases. Previously, it has been demonstrated that PNP has caused the cell cycle arrest at $S$ phase in the many cell types ( $\underline{34})$. Another study has reported that PNP at 5 and $10 \mu \mathrm{M}$ of PNP has arrested the neural stem cell cycle at G2/M phase. The cell cycle arrest at G2/M phases was mainly due to reduced cyclin A and B1 (ㅁ5).

Our morphological study also suggested that changes either in nuclei or cytoplasm might have been due to the abnormal arrangement and functioning of the cytoskeleton. This idea was implied by the protein analysis that associated the PNP exposure to a significant dose dependent reduction in total protein. This event might also be due to the oxidative stresses via reactive oxygen species, causing fragmentation of proteins and oxidation of amino acid side chains.

\section{CONCLUSION}

Our results suggest that PNP reduced the viability and proliferation of MSCs via metabolic and electrolyte imbalances, oxidative stress, reduction in protein synthesis and cell cycle arrest. Therefore, the application of PNP in a variety of industries, such as cosmetics and personal care products, should be stopped. Also, to improve the sewage system's safety, it is necessary to eliminate and destroy the existing PNP sources and to replace it with safe and efficient technologies, while preventing the release of PNP and other pollutants into the environment.

\section{ACKNOWLEDGMENT}

The authors wish to thanks the authorities of University for supporting this project. This study was financially supported by Research Advisory Division, Arak University of Medical Sciences, Arak, Iran.

\section{CONFLICT OF INTEREST}

There was no conflict of interest whatsoever in conducting this study.

\section{REFERENCES}

1. Barahona F, Turiel E. Martín-Esteban A. Determination of Nonylphenol and Nonylphenol Ethoxylates in Powdered Milk Infant Formula by HPLC-FL. Journal of Chromatographic Science. 2011; 49:243-8.

2. Soares A, Guieysse B, Jefferson B, Cartmell E. Nonylphenol in the Environment: A Critical Review on Occurrence, Fate, Toxicity and Treatment in Wastewaters. Environment International. 2008; 34 (7):1033-49.

3. Sengul S,Cevdet U. Nonylphenol in Human Breast Milk in Relation to Sociodemographic Variables, Diet, Obstetrics Histories and Lifestyle Habits in a Turkish Population. Iranian J. Public Health. 2017; 46(4):491-9.

4. Vivacqua A, Grazia Recchia A, Fasanella G, et al. The food contaminants bisphenol $\mathrm{A}$ and 4-nonylphenol act as agonists for estrogen receptor $\alpha$ in MCF7 breast cancer cells. Endocrine. 2003; 22(3):275-84.

5. Bennett ER, Metcalfe CD. Distribution of Alkylphenol Compounds in Great Lakes Sediments, United States and Canada. Environmental Toxicology and Chemistry. 1997;17(7):1230-5.

6. Mao Z, Zheng XF, Zhang $\mathrm{YQ}$, et al. Occurrence and Biodegradation of Nonylphenol in the Environment. Int. J. Mol. Sci. 2012;13(1): 491-505.

7. Ademollo N, Ferrara F, Delise M, et al. Nonylphenol and octylphenol in human breast milk. Environment International. 2008;34: 984-7.

8. Chen ML, Chang CC, Shen YJ, Hung JH, Guo BR, Chuang HY, Mao IF. Quantification of prenatal exposure and maternal-fetal transfer of nonylphenol.Chemosphere. 2008; 73(1): S239-S245.

9. Gautam GJ, Chaube R, Joy KP. Toxicity and tissue accumulation of 4-nonylphenol in the catfish Heteropneustes fossilis with a note on prevalence of 4$\mathrm{NP}$ in water samples. Endocrine Disruptors. 2015;3(1):e981442.

10. Han $\mathrm{XD}, \mathrm{Tu} \mathrm{ZG}$, Gong $\mathrm{Y}$, et al. The toxic effects of nonylphenol on the reproductive system of male rats. Reprod. Toxicol. 2004;19:215-21.

11. Jager CD, Bornman MS, Horst VDG. The effect of pnonylphenol, an environmental toxicant with oestrogenic 
properties, on fertility potential in adult male rats. Andrologia. 1999;31:99-106.

12. Yao G, Hou Y. Nonylphenol induces thymocyte apoptosis through Fas/FasL pathway by mimicking estrogen in vivo. Environ. Toxicol. Pharmacol. 2004;17:19-27.

13. Hughes PJ, McLellan $\mathrm{H}$, Lowes DA, et al. Estrogenic alkylphenols induce cell death by Inhibiting testis endoplasmic reticulum Ca2+ pumps. Biochem. Biophys. Res. Commun. 2000; 277:568-74.

14. Griffith JF, Yeung DK, Ma HT, et al. Bone marrow fat content in the elderly: a reversal of sex difference seen in younger subjects. J. Magn. Reson. Imaging. 2012; 36(1): 225-30.

15. Liu H, Li D, Zhang Y, et al. Inflammation, mesenchymal stem cells and bone regeneration. Histochemistry and Cell Biology. 2018; 149(4):393-404.

16. Abnosi MH, Soleimani Mehranjani M, Momeni HR, et al. The effect of para-nonylphenol on the viability and morphology of rat bone marrow mesenchymal stem cells. Arak Medical University Journal. 2011;14(54):1-11.

17. Abnosi MH, Solemani Mehranjani M, Momeni HR, et al. The induction of apoptosis and autophagy in rats bone Marrow mesenchymal stem cells following in vitro treatment with p-Nonylphenol. Iranian Journal of Science \& Technology A3. 2012; 239-44.

18. Abnosi MH, Soleimani Mehranjani M, Shariatzadeh MA, et al. The effect oflong term treatment of lowest effective dose of paranonylphenol on the viability, morphology and proliferation of rat bone marrow mesenchymal stem cells. Physiol. Pharmacol. 2011;15(3):308-17.

19. Abnosi MH, Soleimani Mehranjani M, Shariatzadeh MA, et al. Para-Nonylphenol Impairs Osteogenic Differentiation of Rat Bone Marrow Mesenchymal Stem Cells by Influencing the Osteoblasts Mineralization. Iran J. Basic Med. Sci. 2012;15(6):1005-14.

20. Abnosi MH, Shojafar E. Treatment of rats with pNonylphenol caused biochemical and morphological changes in bone marrow mesenchymal stem cells. Iran J. Basic Med. Sci. 2015; 18:317-24.

21. Kazemi S, Mousavi Kani SN, Ghasemi-Kasman M, et al. Nonylphenol induces liver toxicity and oxidative stress in rat. Biochemical and Biophysical Research Communications. 2016; 479(1):17-21.

22. Gong Y, Han XD. Nonylphenol-induced oxidative stress and cytotoxicity in testicular Sertoli cells. Reproductive Toxicology. 2006;22(4):623-30.

23. Asifa KP, Chitra KC.Effects of nonylphenol-induced oxidative stress in ovary of cichlid fish, Etroplus maculatus (Bloch, 1795). International Letters of Natural Sciences. 2016;58(11):11-5.
24. Kim SK, Kim BK, Shim JH, Gil JE, Yoon YD, Kim JH. Nonylphenol and octylphenol-induced apoptosis in human embryonic stem cells is related to fas-fas ligand pathway. Toxicol. Science. 2006; 94:310-21.

25. Avelar-Freitas BA, Almeida VG, Pinto MCX, Mourao FAG, Massensini AR, Martins-Filho OA, Rocha-Vieira E, Brito Melo GEA. Trypan blue exclusion assay by flow cytometry. Brazilian Journal of Medical and Biological Research. 2014;47(4):307-15.

26. Liu Y, Peterson DA, Kimura H, Schubert D. Mechanism of Cellular 3- (4,5-Dimethylthiazol-2-yl) -2,5Diphenyltetrazolium Bromide (MTT) Reduction. J. neurochemistry. 1997;69(2):581-93.

27. Abnosi MH, Yari S. The toxic effect of gallic acid on biochemical factors, viability and proliferation of rat bone marrow mesenchymal stem cells was compensated by boric acid. Journal of Trace Elements in Medicine and Biology. 2018;48:246-53.

28. Leekumjorn S, Cho HJ, Wu Y, et al. The Role of Fatty Acid Unsaturation in Minimizing Biophysical Changes on the Structure and Local Effects of Bilayer Membranes. Biochim. Biophys Acta. 2009;1788(7):1508-16.

29. Mulkidjanian AY, Bychkov AY, Dibrova DV, et al. Origin of first cells at terrestrial, anoxic geothermal fields. Proc. Natl. Acad. Sci. USA. 2012;109: E821-E830.

30. Yu SP, Choi DW. Na+-Ca2+ exchange currents in cortical neurons: concomitant forward and reverse operation and effect of glutamate. The European Journal of Neuroscience. 1997;9(6):1273-81.

31. Movahedi Najafabadi B, Abnosi, MH. Boron induces early matrix mineralization via calcium deposition and elevation of alkaline phosphatase activity in differentiated rat bone marrow mesenchymal stem cells. Cell J. 2016;18(1):62-73.

32. Alaa El-Din HS, Rania FKI. Endocrine disruption, oxidative stress, and testicular damage induced by 4 nonylphenol in Clarias gariepinus: The protective role of Cydonia oblonga. Fish Physiology and Biochemistry. 2017;43(4):1095-104.

33. Louis SA, Rietze RL, Deleyrolle L, et al. Enumeration of neural stem and progenitor cells in the neural colonyforming cell assay.Stem Cells. 2008;26(4): 988-96.

34. Colerangle JB, Roy D. Exposure of environmental estrogenic compound nonlyphenol to noble rats alters cell-cycle kinetics in the mammary gland. Endocrine. 1996;4(2):115-22.

35. Kudo C, Wada K, Masuda T, et al. Nonylphenol induces the death of neural stem cells due to activation of the caspase cascade and regulation of the cell cycle. J. Neurochem. 2004;88:1416-23. 